\title{
Analisis Pengukuran Index Kepuasan Masyarakat Kegiatan Praktikum Teknologi Beton Mahasiswa Jurusan Teknik Sipil Tahun 2019/2020 di Laboratorium Struktur Jurusan Teknik Sipil Universitas Brawijaya
}

\author{
Sugeng Hendik Purwanto \\ Laboratorium Struktur Jurusan Teknik Sipil \\ Fakultas Teknik Universitas Brawijaya \\ Email : genk_74@ub.ac.id
}

\begin{abstract}
Abstrak
Laboratorium memegang peranan sangat penting dalam proses kegiatan pembelajaran khususnya di Perguruan Tinggi, hal ini dikarenakan dengan melaksanakan kegiatan praktek di laboratorium mahasiswa dapat mengaplikasikan dan membuktikan teori teori yang didapat selama perkuliahan. Pelayanan laboratorium yang baik akan menghasilkan kualitas data penelitian dan kompetensi lulusan yang baik pula. Untuk melihat sejauh mana kualitas pelayanan laboratorium terhadap mahasiswa maka perlu diadakan pengukuran kinerja yang jelas terhadap layanan laboratorium dengan metode yang standar. Salah satu upaya pemerintah untuk meningkatkan kualitas pelayanan public adalah melalui Keputusan Menteri Pendayagunaan Aparatur Negara Nomor Kep/25/M.Pan/2/2004 tentang Pedoman Umum Penyusunan Indeks Kepuasan Masyarakat Unit Pelayanan Instansi Pemerintah. Penelitian ini menggunakan metode deskriptif dengan pendekatan kualitatif. Teknik pengambilan sampel dengan purposive sampling. Pengambilan data dilakukan dengan pengisian kuesioner pada beberapa sampel. Dari hasil dari penelitian dapat disimpulkan bahwa Berdasarkan 15 unsur penilaian, analisis Indeks Kepuasan Masyarakat (IKM), kualitas pelayanan Laboratorium Struktur pada tahun 2019 diperoleh Nilai persepsi 3, Nilai Rata-rata Tertimbang per unsur sebesar 3,05 dan Nilai IKMunit pelayanan sebesar 76.25 yang berarti bahwa mutu pelayanan Laboratorium Struktur masuk dalam kategori B, sehingga kinerja pelayanannya dikatakan Baik.
\end{abstract}

Kata Kunci : Nilai Persepsi, Interval IKM, Interval Konversi IKM, Mutu Pelayanan dan Kinerja Unit Pelayanan

\section{PENDAHULUAN}

Tuntutan masyarakat dalam hal pelayanan publik terus meningkat, oleh karena itu maka unit penyelenggara pelayanan publik dituntut untuk memenuhi harapan masyarakat dalam melakukan perbaikan pelayanan. Pelayanan publik yang dilakukan oleh aparatur pemerintah saat ini belum memenuhi harapan masyarakat. Selain itu, birokrasi di Indonesia masih berada pada zona tidak kreatif, struktur yang gemuk (tambun), penuh dengan kolusi, korupsi, dan nepotisme (Izudin, 2019).

Begitu kuatnya cengkraman desentralisasi yang selama ini dilakukan dalam pelayanan publik di Indonesia sebelum otonomi daerah menjadi kendala untuk melakukan percepatan reformasi terhadap pelayanan masyarakat (Nurrizka \& Saputra, 2011). Hal ini dapat diketahui dari berbagai keluhan masyarakat yang disampaikan melalui media massa dan jaringan sosial, sehingga memberikan dampak buruk terhadap pelayanan publik, yang akan menimbulkan ketidakpercayaan masyarakat.

Menurut Pasolong (dalam Damayanti et al., 2019) "Semakin baik kepemerintahan dan kualitas pelayanan yang diberikan, maka semakin tinggi kepercayaan masyarakat (high trust)". Kepercayaan masyarakat akan semakin tinggi apabila masyarakat mendapatkan pelayanan yang baik dan merasa terpuaskan akan pelayanan tersebut. Upaya peningkatan kualitas pelayanan publik harus dilaksanakan secara konsisten dan berkesinambungan dengan memperhatikan kebutuhan dan harapan masyarakat, sehingga pelayanan pemerintah kepada masyarakat dapat selalu diberikan secara cepat, tepat, murah, terbuka, sederhana dan mudah dilaksanakan serta tidak diskriminatif. Oleh karena itu, upaya peningkatan kualitas pelayanan kepada masyarakat merupakan kegiatan yang dilaksanakan secara terus menerus dan berkelanjutan oleh semua jajaran aparatur negara pada semua tingkatan. 
Dalam penyelenggaraan dibidang pelayanan kepada masyarakat oleh pemerintah mempunyai peranan penting untuk menyediakan layanan publik sesuai yang telah diamanatkan dalam UndangUndang Nomor 25 Tahun 2009 tentang pelayanan publik, pasal 1 menyebutkan bahwa "Pelayanan publik adalah kegiatan atau rangkaian kegiatan dalam rangka pemenuhan kebutuhan pelayanan sesuai dengan peraturan perundang- undangan bagi setiap warga negara dan penduduk atas barang, jasa dan/atau pelayanan administratif yang disediakan oleh penyelenggara pelayanan publik".

Kepuasan pelanggan didasarkan pada kesesuaian antara harapan pelanggan dengan persepsi yang dirasakan pelanggan dari kinerja yang diberikan oleh pelayan publik. Kondisi kepuasan pelanggan tercipta apabila persepsi bernilai lebih besar atau sama dengan harapan, sebaliknya kondisi ketidakpuasan terjadi apabila persepsi lebih kecil dari harapan (Nurfarida, 2015)

Salah satu upaya pemerintah untuk meningkatkan kualitas pelayanan publiknya, adalah dengan menerbitkan Keputusan Menteri Pendayagunaan Aparatur Negara Nomor Kep/25/M.Pan/2/2004. Dalam keputusan tersebut Pemerintah mewajibkan semua kegiatan yang melibatkan publik untuk melakukan evaluasi terhadap pelayanan yang dilakukan secara periodik. Disebutkan pula bahwa pelayanan kepada masyarakat oleh aparatur pemerintah perlu terus ditingkatkan, sehingga akan mencapai kualitas pelayanan yang diharapkan.

Survei Kepuasan Masyarakat adalah pengukuran secara komprehensif kegiatan tentang tingkat kepuasan masyarakat yang diperoleh dari hasil pengukuran atas pendapat masyarakat dalam memperoleh pelayanan dari penyelenggara pelayanan publik. Peraturan ini bertujuan untuk mengukur tingkat kepuasan masyarakat sebagai pengguna layanan dan meningkatkan kualitas penyelenggaraan pelayanan publik. Dalam penyelenggaraan pelayanan publik, penyelenggara pelayanan publik berkewajiban untuk menyusun dan menetapkan standart pelayanan dengan memperhatikan kemampuan penyelenggara, kebutuhan masyarakat, dan kondisi lingkungan. Sesuai dengan Permen PANRB No. 25 Tahun 2004 tentang Pedoman Standar Pelayanan dalam rangka menyusun, menetapkan, dan menerapkan standar pelayanan perlu diperhatikan prinsip-prinsip sebagai berikut:

1. Sederhana, yakni mudah untuk diikuti, dimengerti, dilaksanakan, dan mudah diukur menggunakan prosedur yang jelas dan biaya yang dapat dijangkau masyarakat atau penyelenggara.

2. Akuntabel, dimana hal-hal yang diatur harus bisa dilakukan dan kepada pihak yang berkepentingan dapat dipertanggungjawabkan.

3. Partisipatif, dalam penyusunannya melibatkan masyarakat dan pihak terkait yang dibahas bersama yang kemudian akan memperoleh keselarasan dari hasil kesepakatan atau komitmen bersama.

Dengan dilakukan dengan mengukur Index Kepuasan Masyarakat secara periodik akan diperoleh manfaat, antara lain:

1. Diketahui kelemahan atau kekurangan dari masing-masing unsur dalam penyelenggara pelayanan publik;

2. Diketahui kinerja penyelenggara pelayanan yang telah dilaksanakan oleh unit pelayanan publik secara periodik;

3. Sebagai bahan penetapan kebijakan yang perlu diambil dan upaya tindak lanjut yang perlu dilakukan atas hasil Survei Kepuasan Masyarakat;

4. Diketahui indeks kepuasan masyarakat secara menyeluruh terhadap hasil pelaksanaan pelayanan publik pada lingkup Pemerintah Pusat dan Daerah

5. Memacu persaingan positif, antar unit penyelenggara pelayanan pada

6. Lingkup Pemerintah Pusat dan Daerah dalam upaya peningkatan kinerja pelayanan;

7. Bagi masyarakat dapat diketahui gambaran tentang kinerja unit pelayanan.

Laboratorium Struktur dan Bahan Konstruksi Jurusan Teknik Sipil Universitas Brawijaya yang mempunyai tugas pokok dan fungsi pelayanan dalam bidang pendidikan, penelitian dan pengabdian masyarakat selalu berusaha berkomitmen memberikan layanan yang baik untuk pengguna jasanya. terutama kepada mahasiswa yang melaksanakan kegiatan praktikum dan penelitian. Laboratorium Struktur dan Bahan Konstruksi dalam satu tahun melayani tidak kurang dari 250 mahasiswa praktikum, 50 orang mahasiswa penelitian dan 200 kegiatan pelayanan pengujian dari luar dalam praktek keharian pasti muncul keluhan keluhan dari pengguna jasa 
(mahasiswa dan masyarakat). Adanya keluhan mahasiswa terhadap pelayanan dan pengelolaan laboratorium terutama dalam kegiatan Praktikum mengindikasikan bahwa pelanggan kurang puas atas pelayanan yang diterima. Keluhan keluhan yang muncul tersebut kalau tidak dikelola secara benar akan mendatang permasalahan yang serius dan akan menjadi polemik yang berkepanjangan. Ketidaktahuan pengelola laboratorium akan kebutuhan pelayanan yang dinginkan mahasiswa dan standar baku pelayanan laboratorium yang tidak diketahui oleh mahasiswa akan menimbulkan persepsi yang berbeda terhadap pelayanan laboratorium. Oleh karena itu Laboratorium Struktur melakukan survei kepuasan masyarakat guna mengetahui berbagai kendala dan capaian kinerja pelayanan untuk digunakan sebagai bahan evaluasi dan perbaikan pada periode berikutnya.

\section{METODE PENELITIAN}

Dalam menyusun Survei Kepuasan Masyarakat ini digunakan daftar pertanyaan (kuesioner) sebagai alat bantu pengumpulan data kepuasan masyarakat penerima pelayanan. Penyusunan kuesioner disesuaikan dengan jenis layanan yang disurvei dan data yang ingin diperoleh dari jenis ataupun unit layanan. Desain bentuk jawaban dalam setiap pertanyaan unsur pelayanan dalam kuesioner, berupa jawaban pertanyaan pilihan berganda. Bentuk pilihan jawaban pertanyaan kuesioner bersifat kualitatif untuk mencerminkan tingkat kualitas pelayanan. Tingkat kualitas pelayanan di mulai dari sangat baik/puas sampai dengan tidak baik/puas. Pembagian jawaban dibagi dalam 4 (empat) kategori, yaitu:

1. tidak baik, diberi nilai persepsi 1 ;

2. kurang baik, diberi nilai persepsi 2;

3. baik, diberi nilai 3;

4. sangat baik, diberi nilai persepsi 4 .

Adapun bentuk jawaban dari setiap unsur layanan diberi nilai persepsi:

D = Tidak ..... (Optional: baik/mudah/sesuai/jelas, dll)

C = Kurang.....(Optional: baik/mudah/sesuai/jelas, dll)

$\mathrm{B}=$ Baik/Mudah/Sesuai/Jelas, (Optionalsesuai kuesioner)

A = Sangat.....(Optional: baik/mudah/sesuai/jelas, dll)

Jumlah Responden dipilih secara penuh jumlah peserta praktikum. Jumlah unsur yang di nilai ada 15 unsur dan jumlah respoden sejumlah 114 mahasiswa perserta praktikum. Unsur Penilaian indeks kepuasan masyarakat terhadap laboratorium Struktur dalam pelayanan Praktikum Mahasiswa yang meliputi 15 unsur pelayanan yang telah ditetapkan oleh unit jaminan mutu Jurusan Teknik Sipil Universitas Brawijaya, yaitu:

- Pembagian kelompok

- Jadual praktikum

- Waktu pelaksanaan praktikum

- Manual Prosedur, Instruksi Kerja, dan Buku Petunjuk praktikum

- Introduksi yang telah diberikan

- Kondisi laboratorium

- Peralatan praktikum

- Kondisi alat.

- kompetensi Laboran .

- Laboran menjawab pertanyaan atau melayani permintaan terkait materi praktikum anda denganbaik.

- Asisten laboratorium

- Asisten laboratorium menguasai seluruh materi praktikum denganbaik.

- Peralatan keselamatan \& kesehatan kerja

- Praktikum yang telah dilakukan dapat membuat mahasiswa mengerti proses dan melaksanakan pengambilan data atau perancangan bahan yang terkait dengan mata kuliah yang sedang atau telah ditempuh. 
Pengumpulan data dilakukan secara langsung kepada responden, yang dijadikan responden adalah mahasiswa yang menempuh praktikum. Kuesioner yang diberikan kepada responden berisikan pertanyaan, dimana alternatif jawaban telah disediakan, sehingga responden hanya memilih jawaban, yang menurutnya paling sesuai. Penyebaran Kuesioner dilakukan dengan membagikan kuesioner yang telah disempurnakan dan kuesioner disebarkan kepada Pengguna jasa, dalam hal ini sebagai responden. Kuesioner tersebut dimaksudkan untuk mengetahui pendapat, harapan, dan persepsi pelayanan laboratorium.

Obyek pengambilan sampel adalah mahasiswa yang mengikuti praktikum. Sedangkan sampel diambil secara simple random sampling, yaitu semua mahasiswa peserta praktikum tahun 2019 . Sampel yang dijadikan responden dalam penelitian ini sebanyak 114 responden teknik analisis data dilakukan dengan menggunakan nilai Indeks Kepuasan Masyarakat (IKM) yang dihitung dengan menggunakan nilai rata-rata tertimbang masing unsur pelayanan. Dalam penghitungan IKM terdapat 15 unsur atau indikator yang dikaji. Setiap unsur pelayanan mempunyai penimbang yang sama. Setiap unsur pelayanan mempunyai penimbang yang sama, Pengolahan data masing-masing dilakukan sebagai berikut:

\section{Pengukuran Skala Likert}

Setiap pertanyaan survei masing-masing unsur diberi nilai, nilai dihitung dengan menggunakan "nilai rata-rata tertimbang" masing-masing unsur pelayanan. Dalam penghitungan survei kepuasan masyarakat terhadap unsur-unsur pelayanan yang dikaji, setiap unsur pelayanan memiliki penimbang yang sama. Nilai penimbang ditetapkan dengan rumus, sebagai berikut:

$$
\text { Bobot nilai rata-rata tertimbang }=\frac{\text { Jumlah Bobot }}{\text { Unsur }}=\frac{1}{X}=N
$$

$\mathrm{N}=$ bobot nilai per unsur

Contoh: jika unsur yang dikaji sebanyak 15 (sembilan) unsur

$$
\text { Bobot nilai rata-rata tertimbang }=\frac{\text { Jumlah Bobot } 1}{\text { Jumlah Unsur }}=\frac{1}{15}=0,066
$$

Untuk memperoleh nilai SKM unit pelayanan digunakan pendekatan nilai rata-rata tertimbang dengan rumus sebagai berikut :

$$
\mathrm{SKM}=\frac{\text { Total dari Nilai Persepsi Per Unsur }}{\text { Total Unsur yang Terisi }} \times \text { NIlai Penimbang }
$$

Untuk memudahkan interpretasi terhadap penilaian SKM yaitu antara 25 - 100, maka hasil penilaian tersebut di atas dikonversikan dengan nilai dasar 25, dengan rumus sebagai berikut:

\section{SKM Unit Pelayanan X 25}

Mengingat unit pelayanan mempunyai karakteristik yang berbeda-beda, maka setiap unit pelayanan dimungkinkan untuk:

a. Menambah unsur yang dianggap relevan.

b. Memberikan bobot yang berbeda terhadap 9 (sembilan) unsur yang dominan dalam unit pelayanan, dengan catatan jumlah bobot seluruh unsur tetap 1 . 
Tabel 1

Nilai Persepsi, Nilai Interval, Nilai Interval Konversi, Mutu Pelayanan dan Kinerja Unit Pelayanan

\begin{tabular}{|c|c|c|c|c|}
\hline $\begin{array}{c}\text { NILAI } \\
\text { PERSEPSI }\end{array}$ & $\begin{array}{c}\text { NILAI } \\
\text { INTERVAL (NI) }\end{array}$ & $\begin{array}{c}\text { NILAI } \\
\text { INTERVAL } \\
\text { KONVERSI } \\
(\text { NIK) }\end{array}$ & $\begin{array}{c}\text { MUTU } \\
\text { PELAYANAN } \\
(\mathrm{X})\end{array}$ & $\begin{array}{c}\text { KINERJA UNIT } \\
\text { PELAYANAN }\end{array}$ \\
\hline 1 & $1,00-2,5996$ & $25,00-64,99$ & $\mathrm{D}$ & Tidak baik \\
\hline 2 & $2,60-3,064$ & $65,00-76,60$ & $\mathrm{C}$ & Kurang baik \\
\hline 3 & $3,0644-3,532$ & $76,61-88,30$ & $\mathrm{~B}$ & Baik \\
\hline 4 & $3,532-4,00$ & $88,31-100,00$ & $\mathrm{~A}$ & Sangat baik \\
\hline
\end{tabular}

Sumber: KEPMENPAN NO. 25 Tahun 2004

\section{HASIL DAN PEMBAHASAN}

Responden adalah peserta praktikum Teknologi Beton Periode semester ganjil 2019/2020 terdiri dari 114 orang dengan komposisi :Jenis Kelamin Laki laki 93 Orang (81.5\%), Jenis Kelamin Perempuan 21 Orang (18.5\%).

Tabel 2

Nilai per unsur layanan

\begin{tabular}{|c|c|c|c|c|c|c|c|c|c|}
\hline \multirow{3}{*}{ NO } & \multirow{3}{*}{ UNSUR LAYANAN } & \multicolumn{8}{|c|}{ JAWABAN RESPONDEN ( 128 Orang) } \\
\hline & & \multicolumn{2}{|c|}{$\mathbf{A}$} & \multicolumn{2}{|c|}{ B } & \multicolumn{2}{|r|}{ C } & \multicolumn{2}{|c|}{ D } \\
\hline & & JML & $\%$ & JML & $\%$ & JML & $\%$ & JML & $\%$ \\
\hline 1 & $\begin{array}{l}\text { Pembagian Kelompok Sesuai } \\
\text { dengan Harapan }\end{array}$ & 36 & 31,58 & 75 & 65,79 & 3 & 2,6315789 & 0 & 0,00 \\
\hline 2 & $\begin{array}{l}\text { Jadwal Praktikum diumumkan } \\
\text { tepat waktu }\end{array}$ & 34 & 29,82 & 74 & 64,91 & 6 & 5,2631579 & 0 & 0,00 \\
\hline 3 & $\begin{array}{l}\text { Waktu pelaksanaan Sesuai dengan } \\
\text { kebutuhan }\end{array}$ & 26 & 22,81 & 54 & 47,37 & 30 & 26,315789 & 4 & 3,51 \\
\hline 4 & $\begin{array}{l}\text { MP,IK dan Buku petunjuk telah } \\
\text { jelas }\end{array}$ & 30 & 26,32 & 70 & 61,40 & 14 & 12,280702 & 0 & 0,00 \\
\hline 5 & $\begin{array}{l}\text { Introduksi praktikum dapat } \\
\text { dipahami }\end{array}$ & 32 & 28,07 & 76 & 66,67 & 6 & 5,2631579 & 0 & 0,00 \\
\hline 6 & $\begin{array}{l}\text { Konsisi laboratorium sudah bersih } \\
\text { dan nyaman }\end{array}$ & 19 & 16,67 & 65 & 57,02 & 22 & 19,298246 & 8 & 7,02 \\
\hline 7 & $\begin{array}{l}\text { Peralatan praktikum dapat } \\
\text { digunakan seluruh praktikan }\end{array}$ & 15 & 13,16 & 70 & 61,40 & 25 & 21,929825 & 4 & 3,51 \\
\hline 8 & Kondisi alat dapat berfungsi baik & 10 & 8,77 & 80 & 70,18 & 18 & 15,789474 & 6 & 5,26 \\
\hline 9 & $\begin{array}{l}\text { Laboran menguasai materi dengan } \\
\text { baik }\end{array}$ & 29 & 25,44 & 83 & 72,81 & 2 & 1,754386 & 0 & 0,00 \\
\hline 10 & $\begin{array}{l}\text { Laboran menjawab pertanyyan } \\
\text { peserta dengan baik }\end{array}$ & 30 & 26,32 & 80 & 70,18 & 4 & 3,5087719 & 0 & 0,00 \\
\hline 11 & $\begin{array}{l}\text { Asisten praktikum menjelasakan } \\
\text { materi dengan baik }\end{array}$ & 36 & 31,58 & 72 & 63,16 & 6 & 5,2631579 & 0 & 0,00 \\
\hline 12 & $\begin{array}{l}\text { Asisten menguasai materi dengan } \\
\text { baik }\end{array}$ & 40 & 35,09 & 68 & 59,65 & 6 & 5,2631579 & 0 & 0,00 \\
\hline 13 & Peralatan K3 tersedia dan berfungsi & 15 & 13,16 & 65 & 57,02 & 30 & 26,315789 & 4 & 3,51 \\
\hline 14 & $\begin{array}{l}\text { Staf Administrasi Lab menjawab } \\
\text { pertanyaan dengan baik }\end{array}$ & 16 & 14,04 & 88 & 77,19 & 8 & 7,0175439 & 2 & 1,75 \\
\hline 15 & $\begin{array}{l}\text { Praktikum yang dilakukan ada } \\
\text { keterkaitan dengan kuliah }\end{array}$ & 38 & 33,33 & 60 & 52,63 & 10 & 8,7719298 & 6 & 5,26 \\
\hline
\end{tabular}


Nilai Indeks Kepuasan Masyarakat (IKM) per unsur pelayanan pada Kegiatan Praktikum dapat dilihat pada tabe lberikut:

Tabel 3

KualitasPelayanan

\begin{tabular}{|c|c|c|c|c|}
\hline No. & UNSURPELAYANAN & $\begin{array}{r}\text { NILAI } \\
\text { INTERVAL } \\
\text { KONVERSI }\end{array}$ & $\begin{array}{c}\text { MUTU } \\
\text { PELAYANAN }\end{array}$ & $\begin{array}{r}\text { KUALITAS } \\
\text { PELAYANAN }\end{array}$ \\
\hline U1 & Pembagian kelompok & 3.29 & A & Sangat Baik \\
\hline $\mathrm{U} 2$ & Jadual praktikum & 3.25 & B & Baik \\
\hline $\mathrm{U} 3$ & Waktu pelaksanaan praktikum & 2.88 & $\mathrm{~B}$ & Baik \\
\hline $\mathrm{U} 4$ & ManuManual Prosedur, petunjuk praktikum & $3 ; 14$ & B & Baik \\
\hline $\mathrm{U} 5$ & Introduksi & 3.33 & B & Baik \\
\hline U6 & Kondisi laboratorium & 2.83 & $\mathrm{C}$ & Baik \\
\hline U7 & Peralatan praktikum & 2.84 & B & Baik \\
\hline $\mathrm{U} 8$ & Kondisi alat & 2,82 & B & Baik \\
\hline U9 & Pelayanan Laboran & 3,24 & B & Baik \\
\hline U10 & Penguasaan laboran ke materi & 3,23 & B & Baik \\
\hline U11 & Pelayanan asisten laboratorium & 3,26 & $\bar{A}$ & SangatBaik \\
\hline U12 & Penguasaan asistent terhdp materi & 3.30 & A & SangatBaik \\
\hline U13 & Peralatan K3 & 2.80 & B & Baik \\
\hline U14 & Pelayanan Staf Administrasi & $3: 04$ & $B$ & Baik \\
\hline U15 & Manfaat praktikum terhadp mata kuliah & $3: 14$ & B & Baik \\
\hline
\end{tabular}

Data tabel 3 di atas menunjukkan dari 15 (empat belas) unsur pelayanan yang diteliti sebagian besar menunjukkan bahwa kualitas pelayanannya sangat baik sebanyak $26.6 \%$ (4 unsur pelayanan), dan baik sebanyak $73.4 \%$ (11 unsur pelayanan).

Tabel 4

Nilai IKM Unit Pelayanan

\begin{tabular}{|l|c|c|c|c|c|c|c|c|c|c|c|c|c|c|c|}
\hline $\begin{array}{l}\text { Unsur } \\
\text { Layanan }\end{array}$ & U1 & U2 & U3 & U4 & U5 & U6 & U7 & U8 & U9 & U10 & U11 & U12 & U13 & U14 & U15 \\
\hline $\begin{array}{l}\text { SNilai } \\
\text { /Unsur }\end{array}$ & 375 & 370 & 330 & 358 & 368 & 323 & 324 & 322 & 369 & 368 & 372 & 376 & 319 & 346 & 358 \\
\hline $\begin{array}{l}\text { NRR/ } \\
\text { Unsur }\end{array}$ & 3,29 & 3,25 & 2,89 & 3,14 & 3,23 & 2,83 & 2,84 & 2,82 & 3,24 & 3,23 & 3,26 & 3,30 & 2,80 & 3,04 & 3,14 \\
\hline $\begin{array}{l}\text { NRR } \\
\text { tertbg/ } \\
\text { unsur }\end{array}$ & 0,22 & 0,21 & 0,19 & 0,21 & 0,21 & 0,19 & 0,19 & 0,19 & 0,21 & 0,21 & 0,22 & 0,22 & 0,18 & 0,20 & 0,21 \\
\hline
\end{tabular}

Sumber : Data diolah

Dari tabel karakteristik Jawaban Responden diatas, didapatkan data data pelayanan sebagai berikut:

Unsur 1 (U1): Pembagian Kelompok Praktikum sesuai dengan harapan anda

36 responden menyatakan sangat Baik, 75 responden menyatakan baik, 3 responden menyatakan kurang kurang baik, menghasilkan Nilai Interval IKM 3,29, Nilai Konversi IKM 82,25 masuk kategori Mutu Pelayanan A dengan Kualitas sangat Baik.

Unsur2(U2): Jadwal Praktikum di umumkan tepat waktu

34 responden menyatakan sangat Baik, 74 responden menyatakan baik, 6 responden menyatakan kurang baik, menghasilkan Nilai Interval IKM 3,25, Nilai Konversi IKM 81,25 masuk kategori Mutu Pelayanan A dengan Kualitas sangat Baik. 
Unsur 3 (U3) : Waktu Pelaksanaan Praktikum Sesuai dengan kebutuhan

26 responden menyatakan sangat Baik,56 responden menyatakan baik, 30 responden menyatakan kurang kurang baik, dan 4 menyatakan tidak baik menghasilkan Nilai Interval IKM 2.89, Nilai Konversi IKM 72,25 masuk kategori Mutu Pelayanan B dengan Kualitas Baik.

Unsur4(U4): MP, IK dan Petunjuk praktikum sudah lengkap dan jelas

30 responden menyatakan sangat Baik,70responden menyatakan baik, 14 responden menyatakan kurang kurang baik, dan 0 menyatakan tidak baik menghasilkan Nilai Interval IKM 3.14, Nilai Konversi IKM 78,5 masuk kategori Mutu Pelayanan B dengan Kualitas Baik.

Unsur 5 (U5): Introduksi yang diberikan mudah dipahami dan mempermudah pelaksanaan praktikum 32 responden menyatakan sangat Baik,76 responden menyatakan baik, 6 responden menyatakan kurang kurang baik, dan 0 menyatakan tidak baik, menghasilkan Nilai Interval IKM 3.23, Nilai Konversi IKM 80,75 masuk kategori Mutu Pelayanan B dengan Kualitas Baik.

Unsur 6 (U6): Kondisi Laboratorium telah bersih dan nyaman

19 responden menyatakan sangat Baik, 65 responden menyatakan baik, 30 responden menyatakan kurang kurang baik, dan 0 menyatakan tidak baik menghasilkan Nilai Interval IKM 2.83, Nilai Konversi IKM 70,75 masuk kategori Mutu Pelayanan B dengan Kualitas Baik.

Unsur 7 (U7) : Peralatan Praktikum dapat digunakan oleh seluruh peserta praktikum

15 responden menyatakan sangat Baik, 70 responden menyatakan baik, 25 responden menyatakan kurang kurang baik,dan 4 menyatakan tidak baik menghasilkan Nilai Interval IKM 2.84, Nilai Konversi IKM 71 masuk kategori Mutu Pelayanan B dengan Kualitas Baik.

Unsur 8 (U8): Kondisi alat dapat berfungsi dengan baik

10 responden menyatakan sangat Baik, 80 responden menyatakan baik, 18 responden menyatakan kurang kurang baik,dan 6 menyatakan tidak baik menghasilkan Nilai Interval IKM 2.82, Nilai Konversi IKM 70.5 masuk kategori Mutu Pelayanan B dengan Kualitas Baik.

Unsur 9 (U9): Laboran menguasai materi dengan baik.

29 responden menyatakan sangat Baik,83responden menyatakan baik, 2 responden menyatakan kurang kurang baik,dan 0 menyatakan tidak baik menghasilkan Nilai Interval IKM 3,24, Nilai Konversi IKM 81 masuk kategori Mutu Pelayanan B dengan Kualitas Baik.

Unsur 10 (U10): Laboran menjawab pertanyaan atau melayani permintaan terkait materi anda dengan baik. 30 responden menyatakan sangat Baik,80responden menyatakan baik, 4 responden menyatakan kurang kurang baik, dan 0 menyatakan tidak baik menghasilkan Nilai Interval IKM 3,23 , Nilai Konversi IKM 80.75 masuk kategori Mutu Pelayanan B dengan Kualitas Baik.

Unsur 11 (U11) : Asisten Praktikum menjelasakan pelaksanaan praktikum dengan sistematis 36 responden menyatakan sangat Baik, 72 responden menyatakan baik, 6 responden menyatakan kurang kurang baik,dan 0 menyatakan tidak baik menghasilkan Nilai Interval IKM 3,26, Nilai Konversi IKM 81.5 masuk kategori Mutu Pelayanan A dengan Kualitas Sangat Baik.

Unsur 12 (U12): Asisten Praktikum menguasai materi dengan baik

40 responden menyatakan sangat Baik, 68 responden menyatakan baik, 6 responden menyatakan kurang kurang baik,dan 0 menyatakan tidak baik menghasilkan Nilai Interval IKM 3,3 , Nilai Konversi IKM 82.5 masuk kategori Mutu Pelayanan A dengan Kualitas Sangat Baik.

Unsur 13 (U13): Peralatan K3 tersedia dan berfungsi dengan baik

15 responden menyatakan sangat Baik,65responden menyatakan baik, 30 responden menyatakan kurang kurang baik,dan 4 menyatakan tidak baik menghasilkan Nilai Interval IKM 2.8, Nilai Konversi IKM 70 masuk kategori Mutu Pelayanan B dengan Kualitas Baik.

Unsur 14 (U14): Staf Administrasi Laboratorium Menjawab pertanyaan atau melayani permintaan terkait pelaksanaan praktikum dengan baik 16 responden menyatakan sangat Baik,88responden menyatakan baik, 8 responden menyatakan kurang kurang baik, dan 2 menyatakan tidak baik menghasilkan Nilai Interval IKM 23.04, Nilai Konversi IKM 76 masuk kategori Mutu Pelayanan B dengan Kualitas Baik.

Unsur 15 (U15): Praktikum yang telah dilakukan dapat membuat mahasiswa mengerti proses dan melaksanakan pengambilan data atau perancangan bahan yang terkait dengan mata kuliah yang 
sedang ditempuh 38 responden menyatakan sangat Baik,60 responden menyatakan baik,10 responden menyatakan kurang kurang baik, dan 6 menyatakan tidak baik menghasilkan Nilai Interval IKM 3.14, Nilai Konversi IKM 78.5 masuk kategori Mutu Pelayanan B dengan Kualitas Baik.

Grafik 1

Nilai Layanan Per Unsur

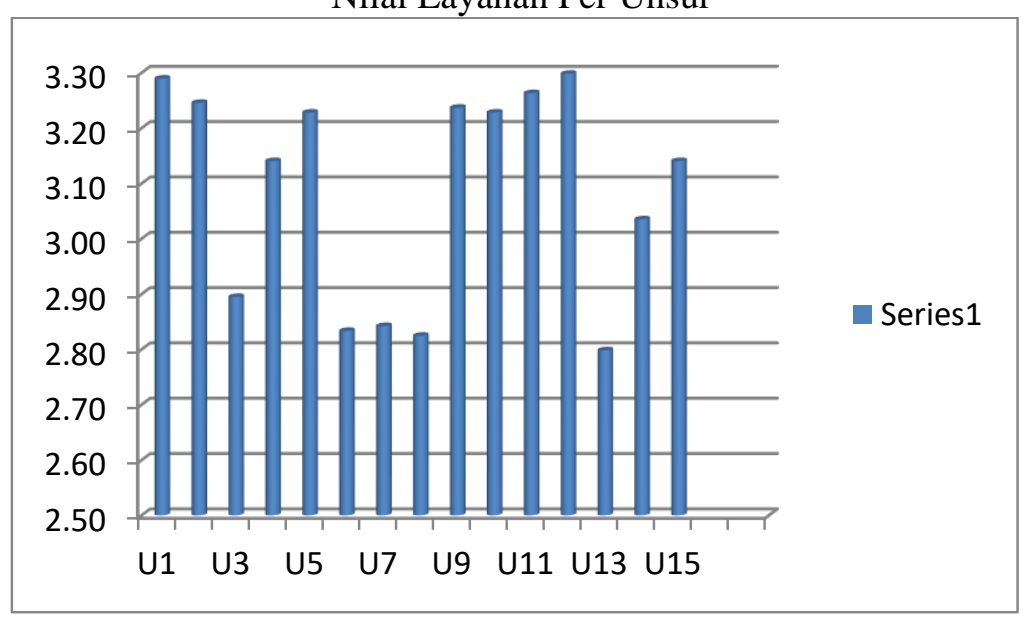

Tabel 6

Ranking Kinerja Pelayanan Tahun 2019

\begin{tabular}{|c|l|r|l|}
\hline NO & \multicolumn{1}{|c|}{ UNSUR LAYANAN } & NILAI & PREDIKAT \\
\hline U12 & Asisten menguasai materi dengan baik & 3,30 & Sangat Baik \\
\hline U1 & Pembagian Kelompok Sesuai dengan Harapan & 3,29 & Sangat Baik \\
\hline U11 & Asisten praktikum menjelasakan materi dengan baik & 3,26 & SangatBaik \\
\hline U2 & Jadwal Praktikum diumumkan tepat waktu & 3,25 & Baik \\
\hline U9 & Laboran menguasai materi dengan baik & 3,24 & Baik \\
\hline U5 & Introduksi praktikum dapat dipahami & 3,23 & Baik \\
\hline U10 & Laboran menjawab pertanyaan peserta dengan baik & 3,23 & Baik \\
\hline U4 & MP,IK dan Buku petunjuk telah jelas & 3,14 & Baik \\
\hline U15 & Praktikum yang dilakukan ada keterkaitan dengan kuliah & 3,14 & Baik \\
\hline U14 & Staf Administrasi Lab menjawab pertanyaan dengan baik & 3,04 & Baik \\
\hline U3 & Waktu pelaksanaan Sesuai dengan kebutuhan & 2,89 & Baik \\
\hline U7 & Peralatan praktikum dapat digunakan seluruh praktikan & 2,84 & Baik \\
\hline U6 & Konsisi laboratorium sudah bersih dan nyaman & 2,83 & Baik \\
\hline U8 & Kondisi alat dapat berfungsi baik & 2,82 & Baik \\
\hline U13 & Peralatan K3 tersedia dan berfungsi & 2,80 & Baik \\
\hline
\end{tabular}

\section{KESIMPULAN}

Berdasarkan 15 unsur/indikator kinerja pelayanan publik yang diteliti pada kegiatan praktikum mahasiswa di Laboratorium Struktur Jurusan Teknik Sipil yang dilaksanakan tahun2019 dengan jumlah responden sebanyak114 orang mahasiswa yang terdiri dari 81,5\% berjenis kelamin laki laki dan $18,5 \%$ berjenis kelamin perempuan , disimpulkan bahwa:

1. Secara umum nilai mutu pelayanan Laboratorium Struktur dalam kegiatan praktikum dengan jumlah responden sebanyak 114 orang pada tahun 2019 diperoleh nilai interval IKM 3,06, nilai indeks kepuasan masyarakat (IKM) sebesar 76.2 dengan Nilai Mutu Pelayanan adalah “ $\boldsymbol{B}$ ” yang berarti Kualitas Layanan lategori BAIK. Ada 3 unsur layanan sudah dinilai sangat baik dan ada 12 unsur layanan dinilai baik, tetapi masih menjadi pekerjaan rumah yang besar untuk menjadikan pelayanan yang 12 unsur ini masih bisa dipacu untuk menjadikan layangan yang sangat baik. 
2. Unsur layanan terbaik di berikan oleh pembagian kelompok; penguasaan asisten dan kemampuan asisten menjelaskan materi dengan mendapatkan indeks IKM 3,30;3,29 dan 3,26. Hal ini bisa terjadi karena pembagian kelompok selalu melibatkan peserta praktikum dan peserta diberikan hak untuk ikut memilih daftar kelompok yang akan akan menjadi rekannya, sehingga diharapkan kekompakan dalam bekerja tim menjadi lebih baik. Penguasaan materi oleh asisten yang baik bisa terjadi karena pola perekrutan asisten yang berjenjang dan berkesinambungan dari angkatan yang lebih tua ke yang lebih muda, sistem seleksi yang ketat dan asisten di breefing terlebih dahulu oleh asisten yang lebih senior dan apabila ada yang kurang jelas selalu didampingi oleh Tenaga Laboratorium, Sehingga asisten benar benar siap dalam menhadapi para peserta praktikum.

3. Unsur pelayanan terendah di peroleh dari kondisi peralatan dan perlengkapan K3 yaitu mendapatkan indeks IKM 2,82 dan 2,80, hal ini terjadi dikarenakan terlalu banyaknya pengguna jasa di Laboratorium Struktur dan Bahan Konstruksi, dan belum diimbangi dengan pengadaan peralatan yang terpisah antara kebutuhan mahasiswa praktikum dan mahasiswa penelitian. Jadi ketika praktikan datang peralatan masih dipakai oleh mahaiswa peneliti dan ada budaya senioritas yang kental antar angkatan sehingga praktikan tidak berani menggunakan alat sebelum diijinkan oleh mahaiswa yang sedang melakukan penelitian. Peralatan K3 memang harus diakui masih jauh dari lengkap, karena memang budaya K3 masih belum melekat dengan baik pada kegiatan sehari hari di Laboratorium, Peralatan K3 yang ada hanya peralatan standar sepeti masker, helm, dan APAR. itupun belum bisa mengcover semua peserta praktikum, kedepan perlu di mulai dilakukan pemisahan Peralatan untuk kebutuhan pendidikan (praktikum) dan kebutuhan peralatan untuk penelitian, sehingga ketika dua kegiatan ini berjalan bersamaan, semua peserta mendapatkan hak dan fasilitas alat yang sama baiknya. Peralatan K3 juga perlu ditambah dengan Safety Shoes, penambahan sarung tangan, sarana P3K dan lain lain. Sehingga semua yang bekerja di laboratorium bias nyaman dan tenang.

\section{SARAN}

1. Untuk penelitian kedepan di harapkan pengukuran Indeks kepuasan Masyarakat ini tidak hanya berhenti pada pelayanan pendidikan saja tetapi kegiatan pelayanan mahasiswa penelitian dan pengguna jasa dari luar juga diukur tingkat kepuasannya,, Sehingga data kepuasan ini menjadi satu kesatuan utuh sebagai indeks kepuasan masyarakat di semua jenjang layanan

2. Untuk tindak lanjut dari hasil evaluasi pengukuran indeks kepuasan pengguna layanan Laboratorium Struktur dan untuk tindakan perbaikan di masa mendatang khususnya kegiatan praktikum bagi mahasiswa, maka perlu penambahan sarana peralatan dan melakukan pemisahan penggunaan peralatan antara kegiatan penelitian dan kegiatan pendidikan (praktikum) dan juga penambahan fasilitas K3 . Sehingga ke depan pengguna jasa laboratorium merasa nyaman dan aman dalam menggunakan fasilitas laboratorium.

\section{REFERENSI}

Damayanti, L. D., Suwena, K. R., \& Haris, I. A. (2019). Analisis Kepuasan Masyarakat Terhadap Pelayanan Publik Berdasarkan Indeks Kepuasan Masyarakat (Ikm) Kantor Kecamatan Sawan Kabupaten Buleleng. Jurnal Pendidikan Ekonomi Undiksha, 11(1), 21. https://doi.org/10.23887/jjpe.v11i1.20048

Izudin, A. (2019). Kepuasan masyarakat terhadap pelayanan publik dalam mewujudkan good governance di Kecamatan Umbulharjo Kota Yogyakarta. Publisia: Jurnal Ilmu Administrasi Publik, 4(1). https://doi.org/10.26905/pjiap.v4i1.2199

Nurfarida, I. N. (2015). Pengukuran Indeks Kepuasan Pelanggan Untuk Peningkatan Kualitas Layanan. Jurnal Ekonomi Modernisasi, 11(2), 135-146. https://doi.org/10.21067/jem.v11i2.874 
Nurrizka, R. H., \& Saputra, W. (2011). Jurnal Manajemen Pelayanan Kesehatan Daftar Isi. The Indonesian Journal of Health Service Management, 14(01), 11-19.

Undang-Undang Republik Indonesia No. 25 Tahun 2009 tentang Pelayanan Publik.Peraturan Menteri Pendayagunaan Aparatur Negara Dan Reformasi Birokrasi Republik Indonesia Nomor 38 Tahun 2012 tentang Pedoman Penilaian Kinerja Unit Pelayanan Publik. 